\title{
KEPEDULIAN PERS TERHADAP PENDIDIKAN \\ (Studi Analisis Isi Berita Pendidikan Anak di Nanggroe Aceh Darussalam Pasca-Bencana Tsunami Pada Harian Kompas dan Harian Media Indonesia)
}

\author{
Ayu Amalia \\ ami.khavid@gmail.com \\ (Dosen Jurusan Ilmu Komunikasi Universitas Semarang)
}

\begin{abstract}
This research is conducted to describe caring extent of Kompas and Media Indonesia towards child education in Nanggroe Aceh Darussalam province after tsunami disaster, using content analysis approach. Data was analyzed using 'intercoder reliability' to measure degree of reliability between coders and media. Agenda Setting and Social Responsibility theories are used to depict media roles on instructing what should be considered by daily readers, in order to portray media social responsibilities, indicating media regard ness. Research final gains, showing that Kompas and Media Indonesia, as printed mass media representations, possessing poor average of caring extent towards child education in post-apocalyptic region, by the amount of 42, $86 \%$. Amongst seven indicators of research, there are only three indicators that refer to significant degree of caring extent foreshortening medias' social responsibility, i.e; news title readability applying substantive method, using comprehendable words; informant selection congruent with news theme; news angle emphasizing certain indicator taken from $5 \mathrm{~W}+1 \mathrm{H}$ concept.
\end{abstract}

Keywords: media's social responsibility, agenda setting, child education, post-disaster Pendahuluan

Fenomena pers dan jurnalisme Indonesia tak luput dari pasang-surut seiring dengan berubahnya faktor internal dan faktor eksternalnya, yang berpengaruh terhadap eksistensi, dan dinamika media massa. Dikemukakan oleh F. Rachmadi (1990) bahwa pers memiliki dua sisi kedudukan, yaitu sebagai media komunikasi tertua dibanding media komunikasi yang lain; dan sebagai institusi sosial merupakan bagian integral dari masyarakat dan bukan merupakan unsur yang tidak dikenal dan terpisah (Nurudin, 2004: 70).

Kondisi sosial masyarakat saat ini yang kian memprihatinkan, media massa, khususnya surat kabar juga turut andil dalam mengangkat nilai-nilai universal kemanusiaan, seperti kepedulian terhadap sesama, keadilan, persaudaraan, dalam membuat berita. Berkaitan dengan hal tersebut, belum lama ini Indonesia adalah salah satu negara yang menjadi sorotan masyarakat Internasional berkenaan dengan bencana tsunami, berikut Thailand, dan negara-negara di kawasan Asia Selatan, serta negara-negara di kawasan Pantai Timur Afrika. Provinsi Nanggroe Aceh Darussalam, dinilai sebagai wilayah dengan dampak kerusakan yang besar dibandingkan wilayah lain yang juga mengalami terpaan bencana tsunami. Bencana tsunami diawali dengan adanya gempa berkekuatan 6,8 skala richter yang melanda kawasan Aceh dan Sumatera Utara dengan pusat gempa berada di Lautan Hindia, tepatnya di pesisir Aceh Barat. Gelombang pasang tsunami ini tidak hanya melanda daerah Aceh dan Sumatera Utara di Indonesia, tetapi juga menyapu 
kawasan wisata pantai Phuket di negara Thailand, kota pelabuhan Chittagong di negara Bangladesh, dan sebagian kawasan di negara Srilanka. (http://www.BMG.org.id/tsunami/berita).

Termasuk dalam hal pendidikan, yang tiba-tiba saja tidak lagi diprioritaskan karena masih banyaknya masalah lain yang lebih penting menunggu untuk diselesaikan, seperti masalah pengungsi dan pengungsian, pengumpulan dan penyaluran bantuan. Tercatat sekitar 300 bangunan sekolah rusak berat, yang mengakibatkan lebih dari 1500 siswa kehilangan kesempatan belajar. Depdiknas setempat mengalami kesulitan melakukan pendataan ulang atas para staf pengajar yang bertugas di daerah NAD dan Sumatera Utara, diperkirakan sekitar 130 staf pengajar belum diketahui keberadaannya. Untuk itu Depdiknas Jakarta berupaya memulihkan kegiatan belajarmengajar di derah tersebut dengan mengirimkan sejumlah relawan dan aktivis badan eksekutif mahasiswa untuk membantu pelaksanaan pendidikan darurat di Nanggroe Aceh Darussalam. Untuk sementara pendidikan darurat telah dilakukan di lima titik pengungsian yaitu disekitar Matai, kecamatan Lhok Nga, Aceh Besar. Proses belajar-mengajar dilaksanakan dengan sarana yang kurang bahkan tidak memadai, untuk materi pendidikan darurat pada tahap awal ini terfokus pada pemulihan kondisi psikologis para siswa yang mengalami trauma setelah mengalami bencana tersebut. (http://www.liputan6.com/tsunami).

Pers sebagai pilar keempat suatu negara atau yang institusi yang dinilai turut mengemban tanggungjawab sosialkemanusiaan mendapat tugas untuk membuktikan upaya kepeduliannya terutama dalam bidang pendidikan sebagai bekal generasi penerus, untuk mengetengahkan sajian berita pendidikan yang diharapkan selain dapat memberikan penerangan, tetapi juga dapat mengundang simpati dan bantuan dari pihak-pihak yang merasa terpanggil, khususnya dalam kasus pemberitaan bencana yang terjadi di NAD. Bantuan dapat berasal dari lembaga-lembaga kemasyarakatan dan pendidikan baik yang bergerak dengan berorientasi pada aspek finansial maupun dalam bidang sosial kemanusiaan, serta warga masyarakat yang lain untuk bersama-sama dengan pihak media (pers), menjadikan pendidikan sebagai salah satu prioritas kebutuhan generasi penerus. Untuk menjadi perhatian pendidikan untuk anak-anak harus dipertimbangkan dari lima aspek yang berbeda, yaitu : fisik, mental, moral, sosial, dan spiritual. Jika satu sisi berkembang dan sisi lainnya tidak, secara alami anak-anak akan menunjukkan beberapa kekurangan dalam perkembangannya. (http://www.pendidikan-

network.org.id/artikel). Oleh sebab itu, pendidikan haruslah dilaksanakan dengan selaras dan seimbang, dengan memperhatikan dan mempertimbangkan aspek-aspek yang ada.

Media cetak, khususnya surat kabar diharapkan dapat menjangkau secara lebih mendalam dengan menampilkan beragam informasi yang dikemas secara khas, diharapkan dapat membantu masyarakat mengetahui kondisi dan situasi masyarakat beserta lingkungannya yang berada di daerah bencana, terutama di provinsi Nanggroe Aceh Darussalam, untuk memberikan bantuan yang dibutuhkan. Terlebih lagi upaya surat kabar dalam mengangkat informasi yang berkenaan dengan dunia pendidikan, karena dengan demikian masyarakat dapat memperoleh deskripsi mengenai keberlangsungan dunia pendidikan di Indonesia dan berupaya membangunnya bersama-sama dengan pihak terkait yang lain.

\section{Tinjauan Pustaka}

Aktualisasi fungsi media tercermin 
pada materi informasi yang disajikan untuk membantu khalayaknya dalam memahami makna dari informasi yang disampaikan dan membentuk kerangka pemikiran berdasar atas informasi yang disampaikan tersebut. Seperti halnya aktualisasi fungsi media dalam membantu membentuk pemahaman khalayaknya tentang dunia pendidikan di Indonesia, baik melaksanakan fungsi mendidik yang melekat dalam proses komunikasi massa yang dilaksanakannya maupun menampilkan ulasan berita yang mengetengahkan topik pendidikan. Untuk itu dikembangkan sebuah pola yang disebut dengan 'skala kemudahan untuk dibaca'(readability) yang dipahami sebagai suatu deskripsi matematis tentang suatu contoh tulisan melalui jumlah kata dalam kalimat, jumlah perkataan poli-silabis (perkataan bersuku kata banyak), kerumitan kalimat, dan karakateristik lain. (Kusumaningrat, 2005: 152).

Masalah pendidikan terkait erat dengan dunia anak, sebagaimana layaknya anak-anak yang tumbuh dan berkembang secara wajar, anak-anak Nanggroe Aceh Darussalam juga memerlukan pendidikan sebagai suatu rutinitas yang dapat turut membangun diri mereka. Mempertimbangkan pendidikan anak-anak sama dengan upaya mempersiapkan generasi yang akan datang. Karena pada anakanaklah keberlangsungan hidup suatu masyarakat, bangsa, negara bergantung sebagai generasi penerus. Oleh karena itu, dalam mempersiapkan dan melaksanakannya haruslah dilakukan dengan sebaik mungkin, secara optimal. Pihak-pihak yang terkait dengan hal tersebut adalah lingkungan keluarga, lingkungan sekolah, dan pemerintah.

Pers sebagai pilar keempat suatu negara atau yang institusi yang dinilai turut mengemban tanggungjawab sosialkemanusiaan, mendapat tugas untuk membuktikan upaya kepeduliannya terutama dalam bidang pendidikan sebagai bekal generasi penerus, untuk mengetengahkan sajian berita pendidikan yang diharapkan selain dapat memberikan penerangan, tetapi juga dapat mengundang simpati dan bantuan dari pihak-pihak yang merasa terpanggil, khususnya dalam kasus pemberitaan bencana yang terjadi di NAD.

Isi tulisan media dalam ulasan berita yang ditampilkan oleh media tertentu, dipengaruhi oleh individu pekerja media, rutinitas media, oraganisasi media itu sendiri, institusi di luar media, dan ideologi. (Shoemaker \& Reese, 1991: 73). Sikap Media yang dalam penelitian ini dinyatakan sebagai kepedulian insitusi media, terkait dengan ideologi media, dimana ideologi tersebut akan mengisi pada masing-masing tingkatan dalam struktur organisasi, baik dari tingkat individu pembuat berita, organisasi rutin sampai faktor-faktor ekstrem yang mempengaruhi media massa. (Sularto, 2001: 97).

Penelitian ini menggunakan besaran frekuensi dalam menganalisis data, yang disajikan dalam setiap tabel. Merupakan bentuk representasi data yang paling umum, yang pada intinya membantu meringkaskan fungsi analisis, berkaitan dengan frekuensi : yaitu frekuensi absolut, seperti jumlah kejadian yang ditemukan dalam sampel, frekuensi relatif, seperti presentase ukuran (size) sampel. Volume ukuran seperti jumlah inci, kolom, waktu, ruang, atau indeks lain yang didasarkan atas frekuensi mempunyai status sama dalam analisis isi dan tidak perlu dibedakan. (Krippendorf, 1997: 168).

Berkaitan dengan penelitian analisis isi ini, frekuensi umumnya merujuk pada perhatian (attention), penekanan/aksentuasi (emphasis), atau kecenderungan (tendency). Menurut Gerbner terdapat empat kelas kategori yang pada umumnya sering digunakan, yaitu : attention, emphasis, tendency (kecenderungan), dan structure (tata susunan). Attention adalah hasil seleksi 
dari fenomena yang dihadirkan. Indikator ukurannya adalah tanda dari kehadiran dan frekuensi dari faktor-faktor persoalan (seperti topik atau tema). Emphasis merupakan faktor dari komposisi sistemsistem pesan yang menetapkan sebuah konteks prioritas atas kepentingan atau keterkaitan. Ukuran emphasis dapat didasarkan pada tanda-tanda atas ukuran, intensitas, atau penekanan sebagai penetapan topik sebagai headline dalam hal berita atau ciri dari topik-topik atau tematema tertentu sebagai acuan terbesar dari cerita-cerita. (Gerbner, et al, 1978: 131).

Dari ulasan berita yang disajikan media cetak, khususnya surat kabar, diharapkan terdapat saluran partisipasi yang dapat berasal dari lembaga-lembaga kemasyarakatan dan pendidikan baik yang bergerak dengan berorientasi pada aspek finansial maupun dalam bidang sosial kemanusiaan, serta warga masyarakat yang lain untuk bersama-sama dengan pihak media (pers), menjadikan pendidikan sebagai salah satu prioritas kebutuhan generasi penerus. Untuk menjadi perhatian pendidikan untuk anak-anak harus dipertimbangkan dari lima aspek yang berbeda, yaitu : fisik, mental, moral, sosial, dan spiritual. Jika satu sisi berkembang dan sisi lainnya tidak, secara alami anak-anak akan menunjukkan beberapa kekurangan dalam (http://www.pendidikannetwork.org.id/artikel). Oleh sebab itu, pendidikan haruslah dilaksanakan dengan selaras dan seimbang, dengan memperhatikan dan mempertimbangkan aspek-aspek yang ada.

Penelitian ini mengangkat perihal pendidikan yang ditujukan untuk anak Indonesia. Anak-anak merupakan generasi penerus bangsa, sekaligus aset dari orangtua, keluarga, dan lingkungannya di masa mendatang, karena dalam diri seorang anak terjadi perkembangan potensi yang kelak akan berharga sebagai sumber daya manusia. Dikemukakan oleh Emmy Soekresno, S.Pd salah seorang praktisi pendidikan yang bergerak dalam pendidikan anak, bahwa anak-anak yang lahir, tumbuh dan berkembang dalam era kompetitif ini dituntut untuk mengembangkan potensi dirinya secara optimal, agar kelak dapat bersaing dengan sebaik mungkin, serta menjawab tantangan lingkungannya dengan memposisikan diri dan melakukan peranan dengan sebagaimana mestinya. (http://www.pendidikannetwork.org.id/artikel).

Pendidikan di daerah pasca bencana tersebut akan dilakukan dalam tahap-tahap tertentu, revitalisasi dan rekonstruksi yang membutuhkan waktu cukup lama dan upaya yang cukup intens. Sebagai langkah awal akan dilakukan pendidikan psikologis yang mengarah pada perbaikan yang mengarah pada peningkatan kualitas psikis anak-anak korban bencana, yang diasumsikan mengalami trauma pasca-bencana, agar nantinya anak-anak Aceh siap untuk kembali bersekolah. Kemudian, dilanjutkan dengan pembangunan dan penyediaan kembali sarana dan prasarana pendidikan. Berkenaan dengan pemberlakuan otonomi daerah dan otonomi pendidikan, diharapkan masyarakat Nanggroe Aceh Darussalam bersedia melibatkan diri untuk membangun pendidikan generasi mudanya bersama dengan pemerintah setempat dalam rangka membangun daerahnya, terutama dalam bidang pendidikan secara mandiri.

Dengan Agenda Setting, surat kabar sebagai media massa berupaya memanfaatkan kemampuannya dalam rangka menyeleksi dan mengarahkan perhatian masyarakat pada gagasan atau peristiwa terkait. Surat kabar memberikan arahan kepada khalayaknya mengenai halhal yang penting dan hal-hal yang tidak penting. Dengan kata lain, agenda media 
akan menjadi agenda masyarakat, karena media mengarahkan kita untuk memusatkan perhatian pada subjek tertentu yang diberitakan media. Ini artinya, media menentukan agenda kita. Terkait dengan bencana yang melanda provinsi Nanggroe Aceh Darussalam, surat kabar melalui pemberitaannya seputar bencana tersebut, terutama yang berkenaan dengan bidang pendidikan anak, mencoba mengarahkan perhatian masyarakat kepada peristiwa itu, dengan harapan anggota masyarakat yang lain sebagai bagian dari warganegara Indonesia turut peduli akan kondisi memprihatinkan tersebut dan bersedia mewujudkan kepeduliannya dengan memberikan bantuan bagi masyarakat Nanggroe Aceh Darussalam.

Media massa mungkin tidak berhasil dalam menentukan apa yang dipikirkan oleh khalayaknya "what to think", akan tetapi justru cenderung mempengaruhi tentang apa yang seharusnya dipikirkan oleh khalayaknya "what to think about". (Littlejohn, 1992: 104). Maka dapat dipahami bahwa ide dasar agenda setting adalah melihat hubungan kausal antara isi media dengan persepsi publik mengenai isuisu apa yang dianggap penting menancapkan sejumlah masalah dan citra ke dalam pikiran khalayak. Dapat dikatakan bahwa media tidak hanya memberikan informasi, tetapi juga menuntun pengalaman khalayaknya, karena pemberitaan media dapat mengatur (materi) pikiran agenda publik dan diskusi.

Terdapat tiga agenda yang saling terkait dalam teori agenda setting ini, yaitu bahwa agenda media akan mempengaruhi agenda publik, sementara agenda publik itu sendiri akhirnya mempengaruhi agenda pembuat kebijakan (pemerintah) disebut sebagai agenda kebijakan. Agenda Setting media massa erat berkaitan dengan agenda khalayak (public agenda) dan agenda kebijakan (policy agenda) (Prisgunanto,
2004: 79).

Setelah bencana gempa dan gelombang pasang tsunami melanda wilayah Nanggroe Aceh Darussalam, dan Sumatera Utara pada 26 Desember 2004 yang lalu media-media massa Indonesia berlomba untuk mengagendakan bencana tersebut sebagai ulasan berita yang mengetengahkan aspek humanisme dalam keprihatinan masyarakat. Harian Kompas dengan rubrik Humaniora dan harian Media Indonesia dengan rubrik khusus Indonesia Menangis. Peristiwa ini secara tidak langsung menjadi agenda publik, para pengelola media berharap pada masyarakat sebagai khalayak media untuk sejalan dengan mereka dan menetapkan bencana itu sebagai agenda keprihatinan nasional. Masyarakat pun mulai merealisasikan kepeduliannya dengan menyalurkan bantuan pada pos-pos penerimaan bantuan, terutama yang diselenggarakan oleh pengelola media terkait. Peristiwa ini segera menyedot perhatian pemerintah, para pembuat kebijakan untuk turut mewujudkan kepeduliannya. Maka terbentuklah agenda publik yang antara lain dilaksanakan guna menetapkan bencana tersebut sebagai agenda keprihatinan nasional, yang juga menyedot perhatian khalayak internasional; mengumpulkan, menampung, menyalurkan dan mengawasi arus sumbangan; menetapkan kebijakan-kebijakan dalam berbagai bidang sehubungan dengan bencana tersebut.

Dengan terbentuknya agenda publik yang diasumsikan juga mempengaruhi terbentuknya opini publik, maka media tersebut dinilai berhasil dalam menerapkan Agenda Setting dan diasumsikan mampu mempengaruhi khalayaknya untuk menetapkan agenda pribadi dan bertindak sesuai dengan (misi) agenda yang dibawa oleh penerapan agenda setting itu sendiri. Kategorisasi yang digunakan dalam penelitian ini, mengindikasikan sikap Media 
yang dinyatakan sebagai kepedulian institusi media cetak (surat kabar) terfokus pada aspek yang menjadi perhatian pers dalam menangani permasalahan pendidikan anakanak. Terdapat dua aspek untuk mengungkap kepedulian institusi pers (media) terhadap pendidikan anak, yang diindikasikan dengan dua aspek, yaitu aspek instrumental dan aspek substansial.

Aspek Intrumental, merupakan aspek kepedulian media terhadap penanganan permasalahan pendidikan anak yang indikator-indikator pengukurannya terkandung secara eksplisit dalam suatu berita. Direpresentasikan dengan indikator teknis, sebagai berikut :

1) Judul berita,

2) Tanggal terbit,

3) Ukuran kolom berita,

4) Letak kolom berita, yang dipahami sebagai penempatan berita dalam tata letak dan susunan halaman surat kabar, penelitian ini mengaplikasikan konsep ruang rubrikasi yang mencakup:

a. Headline yaitu berita utama yang terdapat pada halaman satu atau halaman muka surat kabar.

b. Berita utama yaitu berita yang dianggap sebagai berita paling penting oleh redaksi terletak di luar halaman satu pada sebuah surat kabar.

c. Jangkar yaitu berita yang ditempatkan pada bagian bawah sebuah halaman surat kabar, ditulis secara memanjang sejumlah empat kolom. Berisi ulasan atau analisis terhadap sebuah peristiwa yang menonjol atau aktual.

d. Pojok yaitu opini surat kabar yang ditulis secara singkat, terletak pada bagian sudut halaman surat kabar yang biasanya berisi komentar redaksi atas pernyataan, tindakan public figure, atau atas peristiwa tertentu. e. Artikel berupa opini terhadap suatu wacana atau peristiwa yang menonjol dan aktual pada masanya, yang ditulis oleh penulis lepas.

f. Kolom yaitu tulisan ringan yang ditulis oleh seorang kolumnis tetap disebuah surat kabar, biasanya mendeskripsikan kejadian, opini penulis dan solusi yang ditawarkan untuk memecahkan persoalan.

5) Tema yang dipahami sebagai substansi isi berita, yang meliputi aspek, sebagai berikut: fisik, psikologis, mentalintelektual, moral-spiritual, sosial dan finansial-material.

6) Angle berita, yaitu sudut bidik dalam menyajikan berita yang dimaknai dari substansi yang ada pada alenia pertama mengenai apa yang ditonjolkan di dalamnya, yang meliputi aspek-aspek what, who, where, when, why, how.

Aspek Substansial, merupakan aspek kepedulian media terhadap penanganan permasalahan pendidikan anak yang indikator-indikator pengukurannya terkandung secara implisit dalam suatu berita. Direpresentasikan dengan adanya indikator non-teknis yang digunakan dalam penelitian ini adalah:

a. Gaya Pengungkapan Tulisan pada Judul Berita, yaitu sebagai berikut:

- Judul ditulis secara Substantif, yaitu judul yang ditulis dengan pilihan kata lugas, mudah, sehingga dapat ditarik kesimpulan apakah merepresentasikan keberpihakan atau netral.

- Judul ditulis secara Konotatif, yaitu penulisan judul yang dilakukan dengan pilihan kata berupa ungkapan, pengandaian, atau kata-kata lain yang dapat diinterpretasikan ganda, sehingga sulit untuk 
diidentifikasikan

keberpihakannya.

b. Gaya pengungkapan tulisan pada isi berita; termasuk ke dalamnya jenis berita yang meliputi aspek-aspek sbb :

- Deskriptif, merupakan uraian mengenai peristiwa yang dikabarkan secara lugas, dengan menggunakan gaya bahasa sederhana, ditulis semata-mata untuk memenuhi unsur $5 W+$ $1 H$, tanpa ada penelaahan atau paparan yang lebih komprehensif, biasanya digunakan dalam menuliskan straight news.

- Substantif, merupakan uraian mengenai peristiwa yang dikabarkan dengan memuat unsur timbang-menimbang, analitis, didahului penelusuran fakta secara mendalam, yang disajikan secara komprehensif, yang disertai dengan data dan informasi dari sumber berita yang utama, biasanya digunakan untuk menulis investigative news.

c. Pemilihan narasumber, yaitu sebagai berikut :

- Birokrat (pembuat kebijakan atau pemerintah), yaitu orangorang yang secara formal bekerja untuk kepentingan negara.

- Kaum intelektual (praktisi pendidikan), yaitu orang-orang yang diakui masyarakat karena kepakarannya atau yang disebut sebagai pengamat atau yang memiliki kemampuan tertentu yang diakui oleh publik.

- Relawan (aktivis LSM), yaitu orang-orang yang terlibat langsung dalam memberikan dan menyalurkan bantuan kepada para korban di daerah bencana.

- Guru dan pelajar yang menjadi korban bencana.

d. Fokus informasi, merupakan sudut pandang yang digunakan dalam menyajikan berita, yaitu sebagai berikut:

- Mendukung pemerintah, dengan indikasi menyetujui atau mendorong kebijakan, sikap atau tindakan yang dilakukan oleh pemerintah yang terkait dengan penanganan permasalahan pendidikan anak di NAD pascatsunami.

- Mendukung masyarakat (praktisi \& pelaksana pendidikan) dengan indikasi menyetujui opini, sikap, atau tindakan yang dilakukan oleh masyarakat, seperti praktisi dan pelaksana pendidikan yang terkait dengan penanganan permasalahan pendidikan anak di NAD pasca-tsunami.

- Mendukung pihak asing, yang dapat berupa negara-negara lain, lembaga profit \& non-profit, perseorangan / kelompok, badan-badan PBB - untuk itu media biasanya sekadar bersifat menginformasikan, namun ada kalanya media juga meneruskan misi tertentu yang diemban oleh pihak asing yang memberikan bantuan.

\section{Metode Penelitian \\ Tipe Penelitian}

Tipe Penelitian yang digunakan dalam penelitian ini adalah dengan menggunakan metode analisis isi yang didefinisikan oleh Berelson (1952) sebagai suatu teknik penelitian yang objektif, sistematik, dan menggambarkan secara kuantitatif isi-isi pernyataan suatu komunikasi. (Bulaeng, 2004:164). 
Analisis isi juga didefinisikan sebagai sistem formal yang acapkali digunakan untuk menarik kesimpulan dari pengamatan terhadap isi. (Stempel, 1981:119). Dalam penelitian ini digunakan pendekatan analisis isi pada berita-berita yang disajikan oleh harian Kompas dan harian Media Indonesia.

\section{Populasi Penelitian dan Populasi Sasaran}

- Populasi penelitian yang digunakan dalam penelitian ini adalah harian Kompas dan harian Media Indonesia. Aspek yang melatarbelakangi pemilihan kedua harian tersebut adalah bahwa harian Kompas dan harian Media Indonesia termasuk ke dalam sepuluh besar situs berita yang berangkat dari lingkungan media cetak, yang sering diakses oleh pengguna internet (Prisgunanto, 2004: 38).

- Populasi sasaran yang digunakan dalam penelitian ini adalah harian Kompas dan harian Media Indonesia yang terbit dalam periode tiga bulan, terhitung sejak bulan Januari sampai dengan bulan Maret 2005.

\section{Penentuan Sampel (Sampling)}

Untuk kajian yang menggunakan ukuran yang sama tentang surat-surat kabar yang distribusinya serupa, Guido H. Stempel III (1952) menyarankan sampling yang ditetapkan tidak lebih dari 12 (dua belas) eksemplar. Stempel mengindikasikan bahwa penambahan sampel melebihi 12 unit tidak menghasilkan hasil yang secara signifikan lebih akurat. (Krippendorff, 1997: 97). Teknik pengambilan sample yang diterapkan dalam penelitian ini adalah acak sederhana.

\section{Teknik Pengumpulan Data}

Teknik pengumpulan data yang dilakukan dalam penelitian ini ditempuh dengan cara terlebih dahulu mendokumentasikan harian Kompas dan harian Media Indonesia berdasar periodesasi yang telah dipilih. Kemudian digunakan lembar koding (coding sheets) untuk memasukkan data berdasar kategorisasi yang telah ditetapkan sebelumnya.

\section{Sumber Data}

- Sumber Data Primer yang digunakan dalam penelitian ini adalah harian Kompas dan harian Media Indonesia berdasar periodesasi yang telah ditetapkan sebelumnya.

- Sumber Data Sekunder yang digunakan dalam penelitian ini adalah literatur penunjang, berupa materi yang didapat dari kepustakaan dan sumber lain.

\section{Unit Analisis}

Unit Analisis dalam penelitian ini adalah berita-berita yang mengetengahkan topik pendidikan anak di Nanggroe Aceh Darussalam yang terdapat pada harian Kompas dan harian Media Indonesia.

\section{Recording Unit dan Content Unit}

- $\quad$ Recording Unit dalam penelitian ini adalah informasi (tulisan) dari artikel berita harian Kompas dan harian Media Indonesia yang mendeskripsikan kepedulian media terhadap dunia pendidikan dan permasalahannya.

- Content Unit dalam penelitian ini adalah masalah pendidikan bagi anak-anak di wilayah Nanggroe Aceh Darussalam. 


\section{Penentuan Pengkode (Coder)}

Proses koding dilakukan dengan dibantu oleh dua orang pengkode untuk menghindari subjektivitas peneliti dalam melakukan analisis data. Pengkode terlebih dahulu mendapat pelatihan dari peneliti. Syarat penetapan pengkode adalah sebagai berikut:

1. Memiliki pengetahun akademis dan / atau pengalaman khusus dalam bidang jurnalistik.

2. Memahami kerangka berpikir dan tujuan penelitian sehingga memudahkan penelitian.

Untuk itu ditunjuk dua orang pengkode yang merupakan mahasiswa Jurusan Ilmu Komunikasi, Fakultas Ilmu Sosial dan Ilmu Politik, Universitas Diponegoro, karena memiliki latarbelakang akademis yang sama dengan peneliti, sehingga diasumsikan memiliki pengetahuan akademis yang kurang-lebih sama dengan peneliti; serta memahami kerangka berpikir dan tujuan penelitian yang diharapkan dapat memudahkan penelitian.

\section{Uji Reliabilitas}

Uji reliabilitas yang digunakan dalam penelitian ini adalah metode pengujian "Intercoder Reliability", yaitu uji reliabilitas yang dilakukan antar koder (lebih dari satu orang), yang dilanjutkan dengan menggunakan rumus yang dikemukakan oleh R. Holsti, yaitu sebagai berikut:

$$
C . R=\frac{2 M}{N_{1}+N_{2}} .
$$

Dengan keterangan, sbb: (Bulaeng, 2001: 188).

$$
\text { C.R }=\text { Coefficient Reliability }
$$

$$
\begin{array}{ll}
\mathrm{M} & \begin{array}{l}
\text { = Jumlah pernyataan yang } \\
\text { disetujui dua pengkode }
\end{array} \\
\mathrm{N} & =\begin{array}{l}
\text { = Jumlah objek yang } \\
\text { dikategori }
\end{array}
\end{array}
$$

\section{Hasil dan Pembahasan}

Penelitian ini menerapkan pendekatan analisis isi yang membutuhkan standar reliabilitas. Untuk menghindari subjektifitas, maka selain peneliti dibutuhkan dua koder lain yang turut menentukan tingkat reliabilitas antar koder (Intercoder Reliability), berikut hasil perhitungan tingkat reliabiltas antar koder yang diperoleh setelah melakukan penelitian: $R_{a b}$ yaitu standar reliabilitas antara koder pertama dan koder kedua sebesar 89,96\%; $\quad R_{b c}$ yaitu standar reliabilitas antara koder kedua dengan koder ketiga sebesar $89,96 \% ; \quad R_{a c}$ yaitu standar reliabilitas antara koder pertama dan koder ketiga sebesar 89,66 \%; dengan menerapkan rumus yang dikemukakan oleh R. Holsti guna menentukan tingkat reliabitas antar koder. Berkaitan dengan tingkat persetujuan bersama, Laswell menyatakan pemberian angka menunjukkan kesamaan selangnya 70 $\%$ s.d. $100 \%$ adalah dapat diterima sebagai kepercayaan." (Krippendorf, 1997: 106).

Penelitian ini menggunakan besaran frekuensi dalam menganalisis data, yang disajikan dalam setiap tabel. Merupakan bentuk representasi data yang paling umum, yang pada intinya membantu meringkaskan fungsi analisis, berkaitan dengan frekuensi : yaitu frekuensi absolut, seperti jumlah kejadian yang ditemukan dalam sampel, frekuensi relatif, seperti presentase ukuran (size) sampel. Volume ukuran seperti jumlah inci, kolom, waktu, ruang, atau indeks lain yang didasarkan atas frekuensi mempunyai status sama dalam analisis isi dan tidak perlu dibedakan. (Krippendorf, 1997: 168).

Berkaitan dengan penelitian analisis 
isi ini, frekuensi umumnya merujuk pada perhatian (attention), penekanan/aksentuasi (emphasis), atau kecenderungan (tendency). Menurut Gerbner terdapat empat kelas kategori yang pada umumnya sering digunakan, yaitu sebagai berikut: attention, emphasis, tendency (kecenderungan), dan structure (tata susunan). Sehubungan dengan penelitian ini, terdapat dua aspek yang digunakan sebagai indikator yaitu aspek attention adalah hasil seleksi dari fenomena yang dihadirkan. Indikator ukurannya adalah tanda dari kehadiran dan frekuensi dari faktor-faktor persoalan (seperti topik atau tema). Dan aspek emphasis merupakan faktor dari komposisi sistem-sistem pesan yang menetapkan sebuah konteks prioritas atas kepentingan atau keterkaitan. Ukuran emphasis dapat didasarkan pada tanda-tanda atas ukuran, intensitas, atau penekanan sebagai penetapan topik sebagai headline dalam hal berita atau ciri dari topik-topik atau tematema tertentu sebagai acuan terbesar dari cerita-cerita (Gerbner, 1978: 131). Berdasarkan konsep diatas maka dapat diambil gambaran tentang aspek penekanan dan aspek perhatian pada harian Kompas dan harian Media Indonesia sebagai berikut.

Tabel 1 Distribusi Nilai Aspek Kepedulian pada harian Kompas

\begin{tabular}{|c|c|c|c|c|c|}
\hline No. & Aspek & \multicolumn{2}{|c|}{ Nilai } & \multicolumn{2}{c|}{ Tingkat Kepedulian } \\
\hline & & Tinggi & Rendah & Tinggi & Rendah \\
\hline 1. & Ukuran Kolom & 4 & 10 & & $\sqrt{ }$ \\
\hline 2. & Penempatan Rubrikasi & 4 & 10 & & $\sqrt{ }$ \\
\hline 3. & Gaya Pengungkapan Judul & 14 & 0 & $\sqrt{ }$ & \\
\hline 4. & Gaya Pengungkapan Isi & 3 & 11 & & $\sqrt{ }$ \\
\hline 5. & Pemilihan Narasumber & 14 & 0 & $\sqrt{ }$ & \\
\hline 6. & Fokus Informasi & 5 & 9 & $\sqrt{ }$ & \\
\hline 7. & Angle & 12 & 2 & $\sqrt{ }$ & 4 \\
\hline \multicolumn{2}{|c}{ Jumlah } & & 3 & \\
\hline
\end{tabular}

Tabel 2 Distribusi Nilai Aspek Kepedulian pada harian Media Indonesia

\begin{tabular}{|c|c|c|c|c|c|}
\hline No. & Aspek & \multicolumn{2}{|c|}{ Nilai } & \multicolumn{2}{c|}{ Tingkat Kepedulian } \\
\hline & & Tinggi & Rendah & Tinggi & Rendah \\
\hline 1. & Ukuran Kolom & 6 & 7 & & $\sqrt{ }$ \\
\hline 2. & Penempatan Rubrikasi & 5 & 8 & & $\sqrt{ }$ \\
\hline 3. & Gaya Pengungkapan Judul & 13 & 0 & $\sqrt{ }$ & \\
\hline 4. & Gaya Pengungkapan Isi & 2 & 11 & & $\sqrt{ }$ \\
\hline 5. & Pemilihan Narasumber & 13 & 0 & $\sqrt{ }$ & \\
\hline 6. & Fokus Informasi & 5 & 8 & $\sqrt{ }$ & \\
\hline 7. & Angle & 11 & 2 & $\sqrt{ }$ & 4 \\
\hline \multicolumn{2}{r}{ Jumlah } & & 3 & \\
\hline
\end{tabular}

Berdasar dua tabel diatas dapat ditarik kesimpulan bahwa derajat kepedulian 
media terhadap pendidikan anak NAD pascabencana tsunami berada pada derajat yang sama, yaitu pada derajat rendah. Dari tujuh indikator yang mengindikasikan kepedulian, terdapat tiga indikator yang menandakan kepedulian pada harian Kompas, dan harian Media Indonesia sehingga didapat besaran $42,86 \%$, yang ditunjukkan oleh indikator-indikator berikut:

1. Gaya pengungkapan tulisan pada judul berita yang ditulis secara substantif, dimana judul yaitu judul

yang ditulis dengan pilihan kata lugas, mudah, sehingga dapat ditarik kesimpulan yang merepresentasikan keberpihakan atau netral.

2. Pemilihan narasumber yang sesuai dengan topik sajian berita agar informasi yang didapat dari narasumber dapat dipertanggungjawabkan karena narasumber yang bersangkutan merupakan ahli dalam bidang pendidikan, atau pihak yang mengetahui kondisi daerah pascabencana yang sebenarnya sehingga dapat memberikan keterangan maupun informasi yang sebenar-benarnya kepada khalayak pembaca.

3. Indikator yang turut menunjukkan kepedulian pers yang tinggi atas sektor pendidikan adalah angle berita, dimana berita-berita tersebut menekankan pada salah satu aspek dari konsep $5 W+1 H$, hal ini dimaksudkan agar khalayak pembaca dapat memahami aspek-aspek yang dinilai penting oleh media dalam memberitakan penanganan kasus darurat pendidikan di wilayah NAD pascabencana tsunami, dengan demikian khalayak dapat menilai kebijakan media dalam mempertimbangkan hal tersebut.

Sebanyak 36 eksemplar surat kabar yang ditetapkan sebagai sample secara acak sederhana, terdapat 12 eksemplar surat kabar yang mewakili harian Kompas dan 11 eksemplar surat kabar yang merepresentasikan harian Media Indonesia yang memiliki kandungan berita pendidikan anak NAD pascabencana tsunami. Untuk harian Kompas dari 12 eksemplar tersebut, terdapat 14 berita tentang pendidikan anak di provinsi NAD pascabencana tsunami, sedangkan untuk harian Media Indonesia terdapat 13 berita tentang pendidikan anak di provinsi NAD pascabencana tsunami.

Tingkat kepedulian media yang menjadi objek penelitian ini memiliki dua aspek, yatiu aspek teknis (instrumental) yang terdiri atas kategori ukuran kolom berita, dan penempatan rubrikasi, serta aspek non-teknis (substantif) yang ditunjukkan dengan gaya pengungkapan tulisan pada judul dan isi berita, pemilihan narasumber, fokus informasi, serta angle berita, yang kesemuanya tidak terlepas dari kebijakan institusional media.

Berdasarkan ukuran kolom dengan menggunakan satuan $\mathrm{cm}^{2}$ antara berita pendidikan yang dibandingkan dengan berita yang berkaitan dengan NAD pascatsunami secara keseluruhan, didapat batasan persentase yang berbeda untuk harian Kompas dan harian Media Indonesia. Dapat disimpulkan bahwa kedua harian tersebut cenderung menilai berita pendidikan anakanak NAD pascatsunami sebagai berita yang kurang signifikan, yang ditunjukkan dengan besaran persentase 28, $57 \%$ untuk harian Kompas, dan 46, 15\% untuk harian Media Indonesia, berdasar penghitungan frekuensi relatif.

Berdasar indikator penempatan rubrikasi, harian Media Indonesia dan harian Kompas menilai berita pendidikan anakanak NAD pascatsunami sebagai berita yang 
kurang signifikan, karena berita-berita tersebut ditempatkan pada rubrikasi kolom. Pada harian Kompas, sajian berita pendidikan anak Aceh pascabencana tsunami terdapat pada rubrik Humaniora, yang mengangkat berita seputar perihal kemanusiaan ataupun dalam rubrik Geliat $N A D$ - Sumut, merupakan halaman ataupun kolom tersendiri yang mengangkat perkembangan terakhir wilayah NAD dan Sumut pascabencana tsunami, yang ditunjukkan dengan besaran 71,43\% untuk harian Kompas, sedang untuk berita yang menempati rubrik berita utama adalah sebesar 28,57\%.

Pada harian Media Indonesia, sajian berita pendidikan anak Aceh pascabencana tsunami terdapat pada rubrik DikBud - yang menunjukkan bahwa melalui 'kacamata' harian Media Indonesia berita-berita bidang pendidikan dinilai cukup signifikan, karena yang mengangkat berita seputar bidang pendidikan dan kebudayaan. Sedang dalam rubrik Indonesia Menangis / Menyongsong Fajar Harapan adalah merupakan rubrik yang memuat sajian berita mengenai perkembangan terakhir provinsi NAD dan sebagian wilayah Sumut yang terkena bencana tsunami. Namun, dalam aspek penempatan rubrik, berita pendidikan anakanak NAD pascatsunami lebih banyak dimuat dalam rubrik kolom yaitu sebesar $61,54 \%$, dibandingkan dengan berita-berita yang diposisikan sebagai berita utama yaitu sebesar 38, $46 \%$.

Perbandingan berdasar gaya pengungkapan tulisan pada judul berita, dengan indikator gaya pengungkapan substantif, mengindikasikan kepedulian yang cukup tinggi, karena dengan bahasa yang lugas dan mudah dimengerti oleh khalayaknya, yang diasumsikan dapat menunjukkan keberpihakan atau netralitas media. Analisis terhadap berita-berita yang didapat dari kedua harian tersebut menunjukkan bahwa kedua harian tersebut menunjukkan kepedulian yang tinggi. Harian Kompas dan harian Media Indonesia menunjukkan tingkat kepedulian tinggi sebesar $100 \%$.

Perbandingan berdasar gaya pengungkapan tulisan pada isi berita, dengan indikator gaya pengungkapan substantif, yang mengindikasikan penulisan Investigative News. Yang banyak ditemui dalam analisa data berdasar indikator ini adalah gaya pengungkapan deskriptif yang menggunakan gaya bahasa sederhana, ditulis semata-mata untuk memenuhi unsur $5 \mathrm{~W}+$ $1 H$, yang biasanya digunakan dalam menuliskan Straight News. Karena beritaberita yang dijumpai pada kedua harian tersebut hanya bersifat menginformasikan, memberikan deskripsi kepada khalayaknya tentang perubahan-perubahan yang terjadi seputar kondisi dan situasi bidang pendidikan anak-anak NAD. Tingkat kepedulian yang ditunjukkan dengan indikator substantif pada harian Kompas ditunjukkan dengan angka 21,43 \%, sedangkan pada harian Media Indonesia adalah sebesar $15,38 \%$, sehingga diasumsikan kedua media tersebut memiliki kepedulian yang relatif rendah, karena sebagian besar berita pendidikan ditulis dengan menggunakan gaya pengungkapan tulisan pada isi berita secara deskriptif, sebesar 78,57 \% untuk harian Kompas dan sebesar 84,62 \% untuk harian Media Indonesia.

Perbandingan berdasar kebijakan dalam memilih narasumber ditetapkan standar penilaian bahwa media yang memiliki kepedulian cukup tinggi terhadap pemberitaan penanganan kasus darurat pendidikan di provinsi NAD pascabencana tsunami dengan memilih narasumber yang sesuai dengan topik bahasan yang disajikannya. Sedang dalam distribusi pemilihan narasumber, baik harian Kompas maupun harian Media Indonesia cenderung untuk memilih kalangan birokrat sebagai 
narasumber (ditunjukkan angka sebesar 57, $14 \%$ untuk harian Kompas dan sebesar 61, $54 \%$ untuk harian Media Indonesia), hal ini dimungkinkan karena dalam keadaan darurat pemerintah akan lebih banyak membuat dan menetapkan kebijakan baru, sesuai dengan konteks keadaan, untuk segera menstabilkan ataupun merehabilitasi darurat pendidikan.

Narasumber yang menjadi pilihan terbanyak kedua adalah para guru dan murid yang menjadi korban bencana (pada harian Kompas sebesar 35,71 \%), karena pihak inilah yang akan memberikan deskipsi dan informasi dari kondisi daerah bencana yang sebenar-benarnya. Sementara narasumber lain yaitu relawan (aktivis LSM) dan guru serta pelajar yang menjadi korban bencana pada harian Media Indonesia menempati posisi yang sama ditunjukkan dengan besaran 15,38\%, hal tersebut dapat dilatarbelakangi oleh pertimbangan bahwa harian Media Indonesia menilai peran dari kedua pihak dinilai sama pentingnya bagi revitalisasi dan rekonstruksi pendidikan di NAD.

Perbandingan berdasar fokus informasi, yaitu sudut pandang yang digunakan dalam menyajikan berita. Berkaitan dengan fokus informasi dalam berita, kedua media cenderung mengutamakan fokus informasi pada pihak pemerintah maupun birokrat (yang ditunjukkan oleh angka 64,29\% oleh harian Kompas dan sebesar 61,54\% harian Media Indonesia). Sementara untuk pihak korban bencana dalam menjadi fokus informasi menduduki posisi kedua dengan besaran persentase 28,57 \% untuk harian Kompas dan 15,38 \% untuk harian Media Indonesia, yang dinilai sebagai pihak yang mengetahui kondisi dan situasi riil daerah bencana. Praktisi pendidikan dinilai kurang cukup berperan dalam hal ini, yang ditunjukkan dengan besaran 7,14 \% untuk harian Kompas, karena pada kondisi riilnya, sesuai yang disampaikan dalam berita praktisi pendidikan (kalangan intelektual) tidak cukup berperan dalam revitalisasi dan rekonstruksi pendidikan di NAD.

Perbandingan berdasar pada angle berita yang menekankan pada unsur $5 \mathrm{~W}+1 \mathrm{H}$ dalam menyajikan berita, atau bahkan tidak ada penekanan sama sekali. Pada harian Kompas (ditunjukkan dengan angka 50\%) menekankan pada unsur what dalam menyajikan suatu berita, unsur what biasanya merepresentasikan upaya yang ditujukan dalam rangka rehabilitasi dan revitalisasi sektor pendidikan di provinsi NAD, yang juga ditunjukkan dengan angka dan 30,77 \% untuk harian Media Indonesia.

Sedang untuk unsur who yang biasanya merepresentasikan pihak-pihak yang terkena bencana, pihak pemberi bantuan, pihak pembentuk kebijakan ditunjukkan oleh angka sebesar 35,71 \% oleh harian Kompas, untuk harian Media Indonesia ditunjukkan dengan angka sebesar $53,85 \%$, yang berarti Media Indonesia cenderung lebih menekankan pada unsur who dalam menyajikan berita-berita pendidikan anak NAD pascatsunami. Kedua media diasumsikan memiliki kepedulian yang cukup tinggi dalam menyajikan berita, karena memberikan penekanan pada aspek tertentu yang dapat memudahkan khalayaknya untuk mengambil kesimpulan atas aspek yang berperan paling penting dalam suaut berita. Sedangkan bagi berita yang tidak menekankan pada unsur $5 \mathrm{~W}+1 \mathrm{H}$ (ditunjukkan dengan besaran 14,29\%, untuk harian Kompas, dan sebesar 15,38\% harian Media Indonesia) tidak memiliki unsur yang dikedepankan, diasumsikan sebagai uraian yang memiliki nilai aktualitas saja.

\section{Penutup}

Dinamika bidang pendidikan tanah air, dipengaruhi oleh banyak pihak, pemerintah sebagai pihak yang paling menentukan, melalui kebijakan-kebijakan yang dapat menentukan keberlangsungan 
dan terlaksananya pendidikan itu sendiri, pengelola institusi pendidikan, tenaga pengajar, anak-anak didik, dan praktisi pendidikan yang bersentuhan langsung dengan dunia pendidikan dinilai turut menentukan denyut dunia pendidikan setiap waktunya. Pihak yang menanamkan investasinya dalam bidang pendidikan juga memiliki andil dalam pembangunan bidang pendidikan di tanah air. Tak terkecuali pers.

Pers sebagai pilar keempat suatu negara atau yang institusi yang dinilai turut mengemban tanggungjawab sosial kemanusiaan mendapat tugas untuk membuktikan upaya kepeduliannya terutama dalam bidang pendidikan sebagai bekal generasi penerus, untuk mengetengahkan sajian berita pendidikan yang diharapkan selain dapat memberikan penerangan, tetapi juga dapat mengundang simpati dan bantuan dari pihak-pihak yang merasa terpanggil, khususnya dalam kasus pemberitaan bencana yang terjadi di NAD.

Dari ulasan berita yang disajikan media cetak, khususnya surat kabar, diharapkan terdapat saluran partisipasi yang dapat berasal dari lembaga-lembaga kemasyarakatan dan pendidikan baik yang bergerak dengan berorientasi pada aspek finansial maupun dalam bidang sosial kemanusiaan, serta warga masyarakat yang lain untuk bersama-sama dengan pihak media (pers), menjadikan pendidikan sebagai salah satu prioritas kebutuhan generasi penerus. Untuk menjadi perhatian pendidikan untuk anak-anak harus dipertimbangkan dari lima aspek yang berbeda, yaitu : fisik, mental, moral, sosial, dan spiritual. Jika satu sisi berkembang dan sisi lainnya tidak, secara alami anak-anak akan menunjukkan beberapa kekurangan dalam perkembangannya. (http://www.pendidikan-

network.org.id/artikel). Oleh sebab itu, pendidikan haruslah dilaksanakan dengan selaras dan seimbang, dengan memperhatikan dan mempertimbangkan aspek-aspek yang ada.

Penelitian ini menggunakan harian Kompas dan harian Media Indonesia sebagai objek penelitian, karena kedua harian tersebut telah dikenal masyarakat Indonesia, dan telah menunjukkan kepeduliannya terhadap bidang pendidikan melalui ulasanulasan berita yang mengetengahkan topik pendidikan. Periodisasi penelitian ini dimulai sejak bulan Januari s.d. bulan Maret tahun 2005. Penelitian ini menggunakan metode analisis isi untuk mengkaji beritaberita pendidikan anak-anak NAD psacabencana tsunami yang terdapat dalam harian Kompas dan harian Media Indonesia, sehingga dapat diketahui tingkat kepedulian media terhadap bidang pendidikan, khususnya pendidikan anak-anak di daerah bencana.

Hasil analisis yang diuraikan dalam bab sebelumnya yang menunjukkan tingkat kepedulian yang tinggi dari harian Kompas dan harian Media Indonesia terhadap pendidikan anak di daerah bencana yaitu sebesar 42,86 \%. Adapun rincian kesimpulan dari uraian diatas adalah:

1. Jumlah eksemplar yang digunakan dalam penelitian ini adalah 36 eksemplar untuk tiap-tiap harian. Dalam 36 eksemplar sebagai unit sample yang ditetapkan berdasar teknik pengambilan sample acak sederhana, terdapat 12 eksemplar surat kabar (yakni sebesar 33, 33 \%) yang merepresentasikan harian Kompas, dengan kandungan sebanyak 14 berita pendidikan anak di provinsi NAD pascabencan tsunami di dalamnya. Terdapat 11 eksemplar surat kabar (yakni sebesar 30, $56 \%$ ) yang merepresentasikan harian Media Indonesia, dengan kandungan sebanyak 13 berita pendidikan anak di provinsi NAD pascabencan tsunami di dalamnya. 
2. Berita-berita tersebut diteliti dan dianalisa berdasar dua kategori yang tebagi menjadi tujuh indikator, yaitu kategori teknis (instrumental) yang terdiri atas perbandingan ukuran kolom berita pendidikan dengan ukuran keseluruhan berita NAD pascabencana tsunami dalam besaran persentase, serta penempatan rubrikasi berita. Kategori nonteknis (substantif), yaitu gaya pengungkapan tulisan judul berita secara substantif, gaya pengungkapan tulisan pada isi berita secara substantif, pemilihan narasumber yang sesuai dengan topik sajian, fokus informasi yang menggunakan sudut pandang masyarakat (praktisi pendidikan, para guru dan pelajar yang menjadi korban bencana, para relawan, serta, para aktivis LSM) dan angle berita yang menekankan pada salah satu aspek dari konsep $5 W+1 H$.

3. Tingkat kepedulian yang cukup tinggi pada harian Kompas, yaitu sebesar 42,86\%, ditunjukkan oleh tiga indikator, yaitu : gaya pengungkapan tulisan pada judul berita yang ditulis secara substantif sehingga memudahkan khalayaknya memahami perihal yang ingin disampaikan oleh media sebanyak $100 \%$, pemilihan narasumber yang sesuai dengan topik bahasan sebanyak 100\%, dan angle berita yang mengindikasikan kepedulian tinggi dengan menekankan pada salah satu aspek dari konsep $5 \mathrm{~W}$ $+1 H$ yaitu sebanyak $85,71 \%$.

4. Tingkat kepedulian yang cukup tinggi pada harian Media Indonesia, yaitu sebesar 42, $86 \%$, ditunjukkan oleh tiga indikator, yaitu : gaya pengungkapan tulisan pada judul berita yang ditulis secara substantif sehingga memudahkan khalayaknya memahami perihal yang ingin disampaikan oleh media sebanyak 100 $\%$, pemilihan narasumber yang sesuai dengan topik bahasan sebanyak $100 \%$, dan angle berita yang menekankan pada salah satu aspek dari konsep $5 \mathrm{~W}$ $+1 H$ yaitu sebanyak $84,62 \%$.

\section{Daftar Pustaka}

Andi Bulaeng. 2004. Metode Penelitian Komunikasi Kontemporer. Yogyakarta : ANDI.

Gerbner, George; et al. 1978. The Analysis of Communication Content. New York : Robert E. Krieger Publishing Co., Inc.

Hikmat Kusumaningrat; Purnama Kusumaningrat. 2005. Jurnalistik Teori \& Praktik. Bandung : Remaja Rosdakarya Offset, PT.

Ilham Prisgunanto. 2004. Praktik Ilmu Komunikasi dalam Kehidupan Seharihari. Jakarta : Teraju.

Jalaluddin Rakhmat. 2003. Psikologi Komunikasi. Bandung : Remaja Rosdakarya Offset, PT.

Krippendorff, Klaus. 1997. Analisis Isi Pengantar Teori dan Metodologi. Jakarta : Rajawali Pers.

Littlejohn, Stephen W. 1992. Theories of Human Communication. 4th. Ed., Canada : Wadsworth.

Nurudin. Komunikasi Massa. 2004. Yogyakarta : Pustaka Pelajar.

Shoemaker, Pamela; Reese, S.D. 1991. Mediating The Message : The Theories of Influences on Mass Media Content. New York : Longman. 
Stempel III, Guido H; et al. 1981. Research Methods in Mass Communication.

New Jersey : Prentice - Hall Inc.

ST. Sularto. 2001. Humanisme dan Kebebasan Pers. Jakarta : Kompas Media Nusantara, PT.

http://www.BMG.org.id/tsunami/berita

http://www.Liputan6.com/tsunami

http://www.pendidikannetwork.org.id/artikel 